\title{
An Interdisciplinary Assessment of South Korea's Post-2002 Real Estate Anti-Speculation Policies
}

\author{
JASPER KIM ${ }^{*}$ AND HANNAH JUN ${ }^{* *}$
}

\begin{abstract}
What factors fuelled the South Korean property boom since 2002 , and what (if anything) can be done to prevent a U.S.-style subprime crisis in the local real estate markets? This issue has grown even more urgent given observations of a potential bubble and burst scenario following the U.S. sub-prime crisis. This paper aims to bring together these concerns, from an interdisciplinary regulatory, economic and socio-cultural perspective, by (1) providing a comprehensive and current overview of housing market dynamics in Korea, (2) examining South Korea's real estate regulatory policies since 2002 withstatistical evidence from the Bank of Korea (BOK), and (3) providinga brief policy implication and suggestion sectionregarding the Korean housing market conditions in the post-subprime crisis era.

Keywords: Korea, Real Estate Policies, Regulatory, Culture, Housing Prices
\end{abstract}

\footnotetext{
* Associate professor and department chair of the Graduate School of International Studies (GSIS) at Ewha Womans University (Seoul, Korea). He has been selected as a 2011 Visiting Scholar at Harvard University

* Candidate at the Graduate School of International Studies, Ewha Womans University (Ewha GSIS), and is a former Research Analyst for Lehman Brothers
} 


\section{OVERVIEW OF THE SOUTH KOREAN HOUSING MARKET: KEY FACTORS ASSESSED}

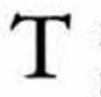

his paper overviews possible factors behind the post-2002 South Korean property boom, in addition to what (if anything) can be done to prevent a U.S.-style subprime crisis in the local real estate markets. Peculiarities in the Korean housing market and notably sharp price fluctuation have made housing price stabilization a key policy goal of the two most recent presidential administrations, presidents Roh Moo-hyun and Lee Myung-bak, respectively. Furthermore, while the debate on the suitability and success of such policies has traditionally been a key focus for the average citizen and the government alike, the issue has grown even more urgent given observations of a potential bubble and burst scenario only a short time after the U.S. sub-prime crisis, and the broader impact this could have on financial markets.

This paper thus aims to bring together these concerns, from an interdisciplinary regulatory, economic and socio-cultural perspective, by (1) providing a comprehensive and current overview of housing market dynamics in Korea, including both economic data sets and cultural variables (such as the baby boom effect); (2) examining South Korea's real estate regulatory policies since 2002 (when President Roh Moo-hyun was elected), with statistical evidence provided of relevant BOK (Bank of Korea) key rates and housing prices; and (3) providingbrief policy implications and suggestionsregarding what path, laissez-faire, Keynesian, or combination of the two, may be most effect to provide stable Korean housing market conditions in the post-subprime crisis era. Thus, the purpose of this paper is to provide an interdisciplinary regulatory and policy assessment of South Korea's real estate anti-speculation policies. Further, because this paper is written from a more regulatory and policy perspective, rather than an economic metric based approach, statistical regression analyses will not be utilized, although some statistical data will be provided and analyzed.

Traditional studies linking demographics and housing prices have partly explained housing price trends in Korea. The effects of the first baby boom spurred property prices during the second half of the Chun Doo-hwan administration, with rising housing price trends further pushed up by the 1988 Seoul Olympics. The succeeding administration under President Roh Tae-woo responded by initiating large-scale housing projects that provided three million housing units, with President Kim Young-sam following with a similar plan which added an additional two million housing units. The combination of an increase in housing supply and the Asian financial crisis in 1997-1998 resulted in a slowdown for the housing market through to 1998, at which point housing supply slowed under then-incumbent President KimDae-jung. Post-crisis recovery and supply shortages led to a housing price rally throughout the Roh Moo-hyun administration, and during the current Lee Myung-bak administration, housing prices have rebounded (although flattening 
again somewhat since the LTV/DTI regulations that began in late 2009) following a brief correction around the time of the U.S. sub-prime crisis.

But while demographics can explain some of the fluctuations in the domestic housing market, it is insufficient in explaining the historically strong preference for housing assets among Korean households. Based on recent surveys, while deposits remain the most favored financial assets, Korean households continue to prefer real estate to securities by a factor of four to one (Kwon et al. 2010). From a cross-country perspective, Korean households have also broadly been shown to have a disproportionately large portion of property holdings at around 65-80percent of total household assets compared to a cross-country average of 55 to 75percent (Davies et al. 2009; Korea National Statistical Office; Kwon et al. 2010). The following sections below suggest that reasons for Korea's overall home bias include structural explanations such as preference for real estate due to the country's leverage system through chonsat (Korea's unique residential rental system that involves making a lump-sum key money deposit to the resident owner in the amount equal to multiples of monthly rent amounts, explained further below), the longevity of the baby boom, and shifting demographics. At the same time, factors such as access to education, higher quality of life, and potential for asset appreciation in specific regions have explained the sharp geographic disparity in housing prices.

\section{Preference for Real Estate in General}

Korean households' preference for real estate in general can be explained by unique features of the domestic real estate market. One such feature is the country's leverage system. While mortgages have become more readily available around the time of the 1997-1998 financial crisis, leverage was traditionally more commonly available in the form of chonsae, an arrangement under which tenants lend a lump sum of money at zero interest rates to homeowners in lieu of monthly rental payments. And while similar private rental markets exist in other OECD countries, Korea noticeably ranks among one of the highest (BIS 2004; Korea National Statistical Office; Kwon et al. 2010). The connection between leverage through chonsae and higher property prices can be explained by examining the long-term, risk-return profile of housing investments with and without leverage versus that of other assets. While average annual yields for one-year central bank paper between 1986 and 2009 was 9.3percent, property investments in Southern Seoul without leverage yielded a rate of return of 7.5 percent per annum over the same period (Kwon et al. 2010). When factoring in leverage through chonsae, the risk-return profiles of housing investments improved sharply vis-à-vis central bank paper and most other assets. Thus given the more attractive risk-return profile on housing investments using chonsae, Korean households may have favored housing investments over investment in other financial assets.

Second, in addition to potential for greater upside of leveraged housing 
investments versus other financial assets, the preference for real estate can also be explained by the longevity of the baby boom and its role in reducing downside risk to housing investments. On the one hand, sustained increases in housing prices and use of leverage have enabled investors in real estate to secure double-digit returns over the long-term, although this trend may be abating recently (as discussed further in this paper). This has laid the foundation for the possibility of housing bubbles (or at the very least, cushions against downside risk) given the appetite for real estate versus other financial assets-particularly for older generation Koreans-coupled with traditionally high national savings rates. On a related note, Korean scholars such as Man Cho argue that, at least in the U.S. case, such housing demand may be due to low "user cost of capital (UCC)," which includes low levels of mortgage rates, low or nominal capital gains taxation from residential property sales, and high expectations of future higher values of residential property (2010).

Third, shifting demographics may also play a role in sustaining the property market. Despite the phase-out of the baby boom generation and the possibility of slowing demand weighing on the real estate market, the deconstruction of the multi-generational, nuclear family into smaller houscholds and single, working adults have the potential effect of mitigating large fluctuations in overall housing dynamics. Specifically, the number of residences that a typical family would require may expand from one to three, with increased demand filtering through to prices and rental rates. Furthermore, the demolition of older housing to clear sites for "new towns" and ocher developments has also left thousands of former tenants on the housing market before the new supply becomes available, effectively working to sustain housing demand in the near-to mid-term (Kim 2009).

\section{Preference for Real Estate in Southern Seoul (Gangnam Area)}

Within the domestic housing market, there has been a distinct preference for real estate in the capital city of Scoul. More specifically, there has been a preference for real estate in the affluent, southern region of the capital, known as Gangnam. One reason for this includes greater access to better educational facilities (Bang 2003). Given that many elite primary and secondary schools as well as private educational institutes are concentrated in Gangnam, demand for housing in Gangnam has traditionally been higher than for other regions in Seoul. As an extension to better access to education, many parents also prefer education in Gangnam so as to increase their children's exposure to children of other well-off families, thus helping to form social cliques which are intended to last their children's lifetime. These observations are generally in-line with the belief that education and social networking are core means by which to achieve prosperity and greater opportunities.

In addition to education, another reason for the preference for real estate 
in Gangnam includes achieving a higher quality of life (Kang 2003). Aspects of this include convenience in commuting from home to work, easy access to public transportation, and a cleaner living environment. Within Seoul, several commercial hubs exist that can be divided into the Gangbuk area and the Gangnam area. While there are an increasing number of businesses being located in the Gangnam area, much commercial activity centers on either City Hall or Yeouido located in Gangbuk. As it relates to commuting by car as well as public transportation, Gangnam's urban planning structure is largely arranged in a grid-like fashion, making commuting much more efficient, tolerable, and faster. This is an important consideration for homeowners given that Korea has a relatively long work-week relative to other industrialized nations. In addition, Gangnam is believed to offer a cleaner, more sanitary environment away from the older Gangbuk area, the latter of which is the historic center of Seoul. For example, higher air quality serves as a motivating factor for potential homeowners looking to raise a family.

Lastly, potential for returns on investment may also explain why Korean households prefer real estate in Gangnam versus other regions. While previous surveys indicate that speculative investment has not been a primary motivating factor for investing in real estate in general, the well-known preference for real estate in Gangnam may have encouraged additional speculative investment in the region.

\section{Rationale for goternment intervention in the real estate market}

On the one hand, government intervention has been traditionally justified on the grounds that the housing market is imperfect and competitive, and has generally relied on a combination of regulation, taxation, and finance in stabilizing the housing market. In Korea's case, the rationale for intervention has further included the historically strong home bias among Korean households-especially in the affluent Gangnam region-and consequently, the potential dangers of extreme housing price fluctuation on the economy and overall financial markets. With regard to this, there has been even more urgency in recent years given the U.S. sub-prime debacle and the possibility of a similar situation in Korea due to a continued increase in mortgage lending and observations of a potential real estate bubble and burst scenario. As a result, designing and executing effective housing policy remains one of the government's key goals.

\section{OVERVIEW OF REAL ESTATE ANTI-SPECULATION POLICIES AND REGULATIONS}

In reviewing the laws and regulations introduced during the Roh Moo-hyun 
and Lee Myung-bak administrations, this section provides a comprehensive overview of the following points: (1) economic environment and housing market dynamics inherited by respective administrations, (2) subsequent policy goals, and (3) specific initiatives introduced to achieve said goals.

\section{Rob Moo-byun Administration (2003-2007)}

(1) Market dynamics: The aftermath of the Asian financial crisis of 1997-1998 and the ensuing weakness in the housing market under Kim Dae-jung (19982002) led to a sharp slowdown in housing supply compared to previous administrations. Following a sudden decline in the Korean housing price index from around 1997, the index remained subdued through to late 2001. But in line with post-crisis recovery, housing prices began to rise again from 2002 and gained further momentum going into the Roh Moo-hyun administration.

(2) Policy goals: From the onset, Roh Moo-hyun had to deal with the post-crisis surge in housing prices fueled in part by the slowdown in housing supply during the previous administration. As such, Roh Moo-hyun's primary objectives included providing more housing opportunities for the ordinary citizen, removing housing market instability, and restraining speculative demand. To achieve this, the objectives of regulations introduced would generally fit into one of three major groups: (1) increasing housing supply, (2) decreasing housing demand, and (3) decreasing housing prices. To meet these objectives, Roh Moo-hyun introduced at least 11 major initiatives during his time in office.

(3) Key initiatives: To provide more housing opportunities for the ordinary citizen, Roh Moo-hyun expanded monetary support for public and rental housing projects, and also provided incentives regarding regulation and taxes to encourage private sector purchases of rental housing unit supply. In addition to monetary support and incentive schemes, the government announced plans to construct five hundred thousandadditional housing units every year from 2003 to 2012-resulting in a total five million housing units to be constructed until 2012-in an effort to better balance housing supply and demand. The development of "new towns" outside the Seoul metropolitan area was also part of a mid-to long-term strategy to increase supply while dispersing housing demand within Seoul.

In a policy objective to reduce housing market instability, most initiatives introduced under Roh Moo-hyun targeted housing demand, specifically speculative demand. Regulations included, (1) controlling demand by regulating supply in order to lower profit from reconstruction and to increase small housing units to strengthen social mix, (2) restrictions on finance for housing in speculative 
zones, and (3) the implementation of taxes on land, property, and capital gains to curb speculative investment. These sub-groups are assessed further as follows.

(1) Controlling demand by regulating supply: Anticipation of the reconstruction of old apartments in many areas of Seoul-which would result in a large number of displaced homeowners looking for housing-was one reason behind steady price increases across the city. As part of the government construction of old apartments in many areas of Seoul-which would result in a large number of displaced homeowners looking for housing-apartments were to be constructed as small houses no bigger than $85 \mathrm{~m}^{2}$. The rationale for this was two-fold. First, the government wanted to prevent prices from rising due to an increase in large-size apartments-especially in the Gangnam area - from which construction companies were able to charge higher prices. Second, the portion of small housing units in reconstruction projects at the time was generally less than 20percent of the total number of housing units. Thus, by controlling supply of large-size units and increasing supply of smaller-size units, the desired result was price stabilization for housing in metropolitan Seoul, particularly in the Gangnam area. Further, in building hopefully more affordable housing for the ordinary citizen, another goal of the government was to diversify and introduce various income classes in the traditionally affluent Gangnam area (i.e., a form of social policy).

(2) Restrictions on finance for bousing in speculative zones: On October 29, 2003. the government announced comprehensive stabilization measures to deal with continued housing price increases. The measures dealt primarily with financing and taxes, with main points including: (1) lowering the loan-to-value (LTV) ratio for mortgage loans from 50 percent to 40percent, (2) increasing capital gains tax rates for those who have more than one home, (3) owners of more than three homes being subject to capital gains tax rates of up to 75 percent, and (4) buyers having to report housing prices to establish a taxation system based on real housing market prices (Kim 2004).

\section{Lee Myung-Bak Administration (2008-Present) Real Estate Policy Overview Includes}

(1) Market dynamics: While real estate prices continued upward throughout the previous administration, the onset of the U.S. subprime crisis, beginning in late 2008, resulted in sharp downward pressure on U.S. housing prices, which then had a spillover effect to downward pressure on Korean housing prices, although not as severe as in the U.S. case. The faster-than-expected recovery in Korean housing prices that followed led to concerns that another potential asset bubble (and burst) situation could be in store.

(2) Policy goals: While the administration was first faced with a decrease in housing prices in light of the U.S. subprime crisis, the faster-than-expected 
price recovery led to concerns that housing prices would continue to increase at a pace that would be difficult for the government to control. In this sense, the administration had to deal with both stimulating demand during the post-U.S. subprime crisis recovery and limiting excessive price increases following the post-crisis rebound in real estate prices, particularly through restrictions on home finance. On the one hand, policies aimed at curbing excessive price increases may have worked too well-the administration was faced with a sluggish housing market by mid-2010 and began to pursue measures aimed at its revival.

(3) Key initiatives: In addressing mid-to long-term stability in housing prices, the administration took efforts to increase housing supply on the one hand, but focused on reducing the risk of reckless lending through restrictions on loan-to-value (LTV) and debt-to-income ratios (DTI) on the other. While LTV considers loan value as a percentage of the market price of the home, D'Tl emphasizes the credibility of mortgage borrowers with respect to their capability in paying back loans.

(4) Restrictions on finance: To address slower demand following the U.S. subprime crisis. LTV and DTl ratios were relaxed for certain areas in October 2008. This was followed by the lifting of various prudential regulations in November 2008, which included the reduction of speculative zones with stricter LTV and DTI ratios to three zones. In addition, tax relief was provided in the case of purchases for multiple homes. Aside from LTV and DTI ratios, the administration in December 2008 also reduced the number of years after which apartments can be resold from five to ten years previously to one to seven years. Tax cuts of 50percent were also announced in February 2009 on proceeds for new houses bought that year in the area surrounding Seoul and sold within the following five years (Ministry of Land, Transport and Maritime Affairs).

With the relatively quick recovery in housing prices that followed, the administration began to tighten financing restrictions to prevent further price instability in the market. With the exception of mortgage loans valued below 50 million won, LTV ratios were tightened from 60 percent to 50 percent in the Seoul metropolitan area in July 2009, a move reminiscent of the previous Roh administration's policies. This excluded the speculative zones as LTV ratios were even tighter. In September 2009, DTI ratios of 50 percent to 60 percent were also introduced in the metropolitan area (similar once more to the previous Roh administration's policies), again with the exception for mortgage loans valued below 50 million won and for more strictly-regulated speculative zones (Ministry of Land, Transport and Maritime Affairs).

But since October 2009 through to August 2010, apartment transactions fell by 45 percent and were at a 16-month low. And while the stock of unsold 
residential properties was 35 percent below its 2009 peak in August 2010, that still represented more than 1.2 times the average between 2001 and 2007 (Lueth 2010). Given the slump in the housing market, the construction sector was negatively impacted with share prices of construction companies clearly under performing in 2010. In response to this, the administration announced a set of measures on August 2010. These included the lifting of DTI limits for lowand middle-income households in possession of less than two properties until March 2011, while excluding propertied valued over 900 million won and properties located within the three speculative zones in the Seoul area. In addition, households whose annual income totaling less than 40 million won would be able to receive a loan of up to 200 million won at an annual interest rate of 5.2 percent. This would not apply, however, to properties valued at above 600 million and those located within the three speculative zones (Ministry of Land, Transport and Maritime Affairs).

\section{POLICY IMPLICATIONS AND SUGGESTIONS}

In South Korea, policy makers are taking determined cfforts to stabilize property prices, before they turn into broader economic problems due to asset price appreciation. But as regulators are discovering, calibrating with any degree of certainty exactly where the normal market ends and a bubble begins can prove challenging.

Prices have been trending downward since late last year. According to the Ministry of Construction and Transportation, the number of apartment transactions (homes sold) in the first three months of the year in the three hottest "speculation zones" of Gangnam, Seocho and Songpafell to 364 (in terms of total residential real estate transactions), a drop of nearly 78 percent from a year earlier. In the ultra-exclusive Gangnam district, average prices fell 2percent in April alone.

Korea was one of the first countries to rebound from the negative effects of the subprime crisis. One reason for this was the historically low interest rates set by the BOK, where prices quickly bounced back from March 2009 onwards, up until the introduction of the original set of debt-to-income and loan-to-value cap restrictions in September 2009 (Cho 2010).

Household debt also notably increased following the BOK's cut in interest rates from late 2008 to quell the crisis. But such debt began to subside somewhat with the debt-to-income restrictions in 2009 and increasing speculation that the BOK would soon execute its crisis "exit strategy" by increasing its key rate. However, much of such debt residue still exists today. For example, of the 418.9 trillion won in household borrowing from banks and institutions like credit unions between April and June this year, 82percent is collateralized by residential property. For this reason, the government now is keen to offset the 
property-price-dampening effects of rising interest rates by using other policy levers to encourage home buying and, as a result, higher house prices (Kim 2009). From 2002 to 2008 (pre-crisis period), the main factors that propelled real estate demand was, as noted earlier, the demographic and socio-cultural factors previously noted in this paper's first section, in addition to UCC determinants (also noted in this paper's first section).

Figure 1. Historical. Bank of Korea (BOK) Target Rate anid Seven-Day REPURCHASE RATE

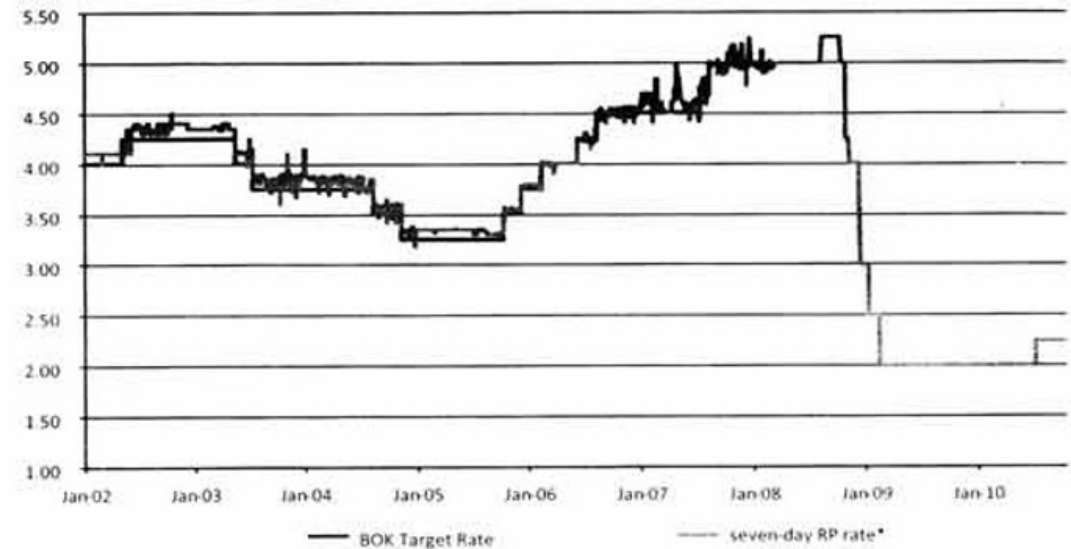

NOTE: as seven-day repurchase rate data is only available from March 7, 2008. call rate data was used as seven-day repurchase rate data tefore March 7, 2008.

SOURCE: Bink of Korea (BOK)

Figure 2. Domestic Housing Price Trends

$(2008.12=100)$

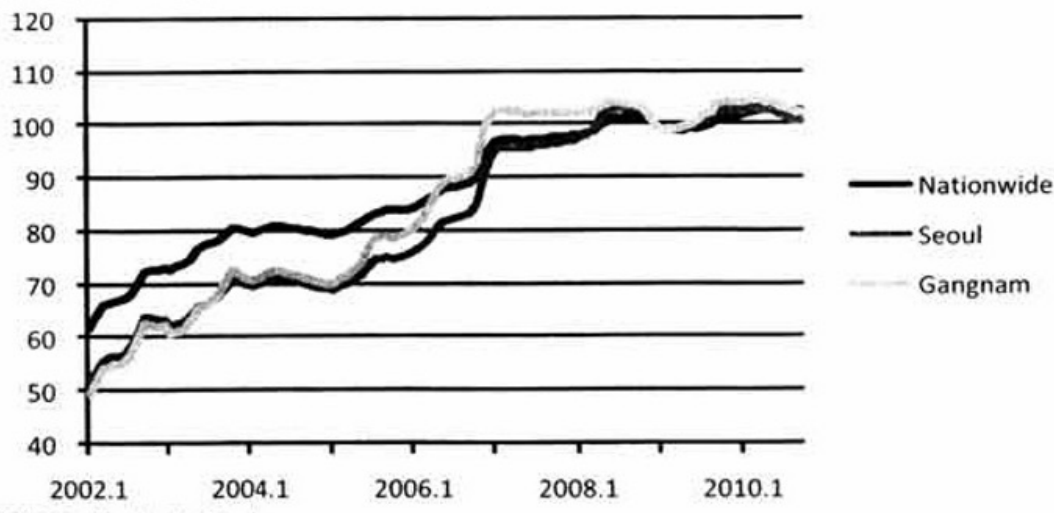

SOURCE: Kookmin Bank. 
The related challenge is that any further efforts to boost prices will only deepen the market's confusion over real-estate policy. For the past 10 years, Korea has witnessed a constant oscillation effect between warming and cooling real estate policies. For example, during the presidency of Roh Moo-hyun from 2003 to 2008, the government implemented a complex set of "anti-speculation" regulations, mostly consisting of heavy real-estate-related taxes. Conversely, upon taking office in early 2008, current President Lee Myung-bak quickly abolished many of those measures. Then, in another apparent reverse course in late 2009. the administration introduced the debt-to-income and loan-to-value restrictions, which Seoul has since lifted, until March 2011.

For this reason, due to an apparent perceived lack of clarity in terms of real estate regulatory policies over the past several years during the course of two administrations, prospective property buyers could-as rational actors trying to mitigate future perceived risk in terms of uncertain regulatory risk-take a "wait and see" approach on real estate regulations after March 2011 when the DT1 cap restrictions are set to expire (or not, as it is yet unclear what will happen afterwards). Similarly, some scholars argue that such lack of clarity in the nation's real estate policies link to a "risk averse" mindset by government bureaucrats (Kim and Kim 2005). Korea's policy makers are correct to worry about the possible effects of rising interest rates on an economy where households are so heavily indebted. At the same time, it would be better for policy makers to look for ways to create greater transparency and certainty in the property market.

As part of the solution, regulators could, for instance, require that banks inform mortgage borrowers of their likely monthly payment obligations at various interest-rate levels. Regulators could also encourage banks to offer more fixed-rate mortgage products since most (but not all) Korean mortgages are based on a floating (rather than fixed) rate (Kim 2009). This means that when the BOK's key rates increase to their long-term equilibrium rates of approximately 4percent (compared to their current 3.0 percent rate), monthly mortgage payments for many Korean households are set to increase, perhaps dramatically, given that the BOK's key rate ranged from 4.0 to 4.5 percent prior to the 2008 subprime crisis. Scholars such as Kyoung-hwan Kim and Man Cho have also agreed that the structural change in mortgage lending has impacted demand for real estate since the early 2000s, and thus, this effort would help to mitigate the excess liquidity in the mortgage lending markets (Kim and Kim 2010).

While most of the world economies are desperately trying to deleverage, what is unique to Korea is that it is desperately seeking more such leverage, rather than attempting to deleverage. Hopefully, such leveraging of personal debt at historically high levels will not lead to the sort of hard landing and dramatic unwinding seen in the U.S., UK, and elsewhere following their real estate bubbles. However, if not, Korea may undergo another national economic crisis not seen 
since Korea's credit card crisis earlier this decade in 2003 (whereby nearly 10percent of its working population were rendered credit delinquent), or worse, the 1997 Korean financial crisis. According to the Korea Credit Bureau, mortgage loans and credit loans rose 9.5 percent and 19.4 percent, respectively from 2009 to 2010, while loans to poor credit (at or near subprime level) account have steadily increased from 54.6 percent of total lending (as of the end of 2008), 55.8 percent (as of the end of 2009), and 57.8 percent (as of the end 2010). Such data bears some similarities with the U.S. subprime crisis, although any potential "Korean subprime crisis" would be less severe than the U.S. case since zero percent down payment mortgage loans do not exist in South Korea, as they did in the U.S. case (Korea Credit Bureau 2011).

To keep Korea's housing bubble from developing any further, policy makers must continue its various DTI and LTV recalibration efforts in addition to more calculated statement releases which clearly spell out that rates must inevitably increase. To their credit, the $\mathrm{BOK}$ and other regulatory authorities have made note of the increase in housing prices. But more direct language aimed at the average citizen is needed. Providing such direct language may be the simplest and most effective way of stabilizing Korea's rapidly rising real estate prices while avoiding a potential real estate meltdown.

A collapse in Korea's real-estate market would not reverberate as widely abroad as the U.S. subprime meltdown. At the same time, it would still be a significant problem for Korean households and for an economy that has so far led the path to recovery. In short, regulators should further heed the lesson from the American experience and act to pre-empt a bubble and stabilize the local real estate markets before homebuyers are forced to realize too late how "unreal" the nation's real estate prices may have become. As such, the links between the population and demographic shifts provided in this paper, along with South Korea's socio-cultural proclivities discussed herein, represent important variables within the assessment of the nation's post-2002 real estate anti-speculation policies.

\section{REFERENCES}

Bang, Hyun-chul. 2003. 강남구 교육 환경 좋아산다 (Education and Environment as Main Reason People Want to Live in Gangnam). ChosunIlbo newspaper: September 13.

Bank of Korea (from Graph). Bank of Korea website, at www.bok.or.kr.

Debelle, Guy. 2004. Macroeconomic implications of rising houschold debts. BIS (Bank of International Settlements) Working. June: 153.

Cho, Man. 2002. Securitization and Asset Price Cycle: Causality and Post-Crisis

Policy Reform. KDI School Working Paper Series, Working Paper 10-08. Preliminary Draft, July 16, 2011, available at http://www.kdischool.ac.kr/new/ 
data/WP10-08.pdf.

Davies, James B., Susanna Sandstrôm, Anthony B. Shorrocks, and Edward N. Wolff. 2009. The Level and Distribution of Global Household Wealth. NBER Working. November: 15508.

Kang, Se-jun, 2003. 중고생 둔 학부모 56percent "교육 때문에 강남 산다 (56 percent of Parents Who Have Junior and High School Students List Education and Environment As Main Reasons For Wanting to Live in the Gangnam Area. Hankyoreh newspaper.

Kim, C. H. and K. H. Kim. 2005. The Political Economy of Korean Government Policies on Real Estate. Urban Studies 37(7): 1157-1169.

Kim, K. H. and M. Cho. 2010. Structural Changes, Housing Price Dynamics, and Housing Affordability in Korea. Housing Studies 25(6): 839-846.

Kim, Jasper. 2004. Anti-Speculation Laws and their Impact on the Real Estate and Financial Markets: the Korean Case. Columbia Journal of Asian Law 18(1). Kim, Jasper. 2009. The Coming Korean Bubble. The Wall Street Journal, October 13.

Kookmin Bank [from Graph], Kookmin Bank website, at www.kbstar.com. Korea Credit Bureau, Korea Credit Bureau website, at www.kcb.or.kr.

Kwon, Goohoon, Chiwoong Lee, Yuriko Tanaka, 2010. Baby Boom and Ageing, Property Boom and Bust: Why Korea Will Not Follow Japan's 1990s Experiences. Goldman Sachs Global Economics, Commodities and Strategy Research, June 11.

Lueth, Erik. 2010. New Measures to Revive the Housing Market. The Royal Bank of Scotland Non-Japan Asia Economics, August 30. 